\title{
Optical infrared-sensor inside the cylinder to determine the EGR- and residual gas rate in diesel engine
}

\begin{abstract}
To meet the increased demands of new exhaust and $C O$, limits a research project of Volkswagen $R \& D$, the Technical University of Poznan and the Ostfalia University of Applied Sciences has been initiated; its main target was the development and adaptation ICOS (Internal Combustion Optical Sensor) - an infrared sensor of LaVision for on-line measurements of EGR-rate in cylinder of an engine under operation. The objective of the project was to determine by different optical signals the $\mathrm{CO}_{2}$ concentration, the EGR rate and residual gas which are cycle-resolved in the cylinder. In this paper the principle of measurement of optical indication has been described. The infrared sensor was validated by a one-cylinder diesel engine and compared to a synchronously running fast gas sampling system (CSV). Finally the practical application of various parameter variations is illustrated in the determination of the EGR and residual gas rate. Thus a new measurement technique for the development of future generations of engines introduced.
\end{abstract}

Keywords: exhaust gas recirculation, IR-sensor, engine research

\section{Optyczny czujnik podczerwieni wewnątrz cylindra w celu określenia recyrkulacji spalin i reszty spalin w silniku wysokoprężnym}

\begin{abstract}
Aby umożliwić spetnienie wymagań nowych norm emisji spalin oraz spetnić limity emisji $\mathrm{CO}_{2}$ podjęto projekt badawczy z udziałem: Volkswagen R\&D, Politechniki Poznańskiej i Ostfalia University of Applied Sciences; jego głównym celem byt rozwój i adaptacja ICOS (Internal Combustion Optical Sensor) - czujnika podczerwieni firmy LaVision dla bieżacych pomiarów stopnia recyrkulacji spalin w cylindrze pracującego silnika. Celem projektu było określenie na podstawie różnych sygnałów optycznych wartość stężenia $C_{2}$, stopnia recyrkulacji spalin (EGR - rate) oraz ilości spalin, które znajdują się w cylindrze przed rozpoczęciem procesu spalania. W artykule przedstawiono zasadę pomiaru zawartości spalin z wykorzystaniem czujnika optycznego. Możliwość zastosowania czujnika podczerwieni została potwierdzona przez badania na jednocylindrowym silniku wysokoprężnym, a otrzymane wyniki porównano z systemem do szybkiego pobierania próbek gazu (CSV). Przedstawiono również wyniki pozwalające na określenie recyrkulacji spalin oraz reszty spalin przy różnych parametrach pracy silnika. Nowa technika pomiarowa pozwala na dostosowanie nowoczesnych silników spalinowych do przyszłych norm ochrony środowiska i tworzy podstawę dla rozwoju przyszłych generacji silników spalinowych.
\end{abstract}

Słowa kluczowe: recyrkulacja spalin, czujnik podczerwieni, badania silnikowe

\section{Introduction}

A good uniform distribution of the EGR rate and a uniform residual gas mass on all cylinders are the basic requirements for a suitable serial combustion method in compliance with the emission limits which simultaneously contain low fuel consumption. Of crucial importance for the optimal design of current and future combustion methods is the accurate recording of the equal uniform distribution and the residual gas in the cylinder. The current measuring technique is a gas analysis with a fast sampling valve. This technique is of limited suitability because it can neither measure cycleresolved nor is the measuring accuracy sufficient nor is the handling of the entire engine simple. Thus, the interpretation

\section{Wstęp}

Równomierny rozkład stopnia recyrkulacji spalin oraz reszty spalin w cylindrze we wszystkich cylindrach silnika wielocylindrowego jest dziś podstawowym wymaganiem dla równomiernego przebiegu procesu spalania z zachowaniem norm emisji, który jednocześnie pozwala na osiągnięcie małego zużycia paliwa. Kluczowe znaczenie dla optymalnego projektowania obecnych i przyszłych systemów spalania jest dokładne określenie równomiernego rozdziału spalin oraz określenie reszty spalin w cylindrze. Obecnie stosowane techniki pomiarowe wykorzystują analizę spalin z wykorzystaniem szybkich zaworów do pobierania próbek z cylindra. Taka technika ma ograniczoną przydatność, ponieważ nie 
and evaluation result nowadays from simulation and the indirect path of gas exchange analysis.

\section{Experimental setup}

\subsection{ICOS System}

The ICOS System (Internal Combustion Optical Sensor) is based on the application of the optical sensor mounted in the cylinder of an engine. The measuring principle of the sensor is a non-contact measuring method and based on the absorption of infrared light by the considered molecular species. The light source is a spectral broadband halogen lamp. The light is modulated by a chopper-wheel at $30 \mathrm{kHz}$ and passed through optical fibers into the measuring section at the cone point of a glow plug probe. By means of a mirror, the light is reflected into a second fiber and consequently reaches the detection unit. The IR band-pass filter which is set in front of the detector determines which molecules species shall be examined. Based on this principle many studies for detection of fuel in engines have been carried out and these are presented in works $[1,2]$.

The introduced system has been slightly amended to detect the light absorption of $\mathrm{CO}_{2}$ molecules in the midinfrared spectral range of round $2.7 \mu \mathrm{m}$. However, also water molecules are able to absorb at this wave length (see Fig. 1). For this reason two detection units were used synchronously. On the one hand, a wide band-pass filter which is covering both the absorption band of the $\mathrm{CO}_{2}$ molecules and parts of the $\mathrm{H}_{2} \mathrm{O}$ molecules (filter exhaust) and on the other hand, a smaller band-pass filter which only detects the absorption by $\mathrm{H}_{2} \mathrm{O}$ molecules (filter $\mathrm{H}_{2} \mathrm{O}$ ). Therefore, after editing this two investigated relative densities, it is possible to cover up the concentration of $\mathrm{CO}_{2}$. The procedure for the separation of signals are described in detail in paper [3].

A careful analysis of the filter cross sections in the used system showed a proportionality factor $\chi$ of 0.8 for the compensation of the water density. This results the following correlation for the connection between the infrared measurement signals and the concentration of $\mathrm{CO}_{2}$ :

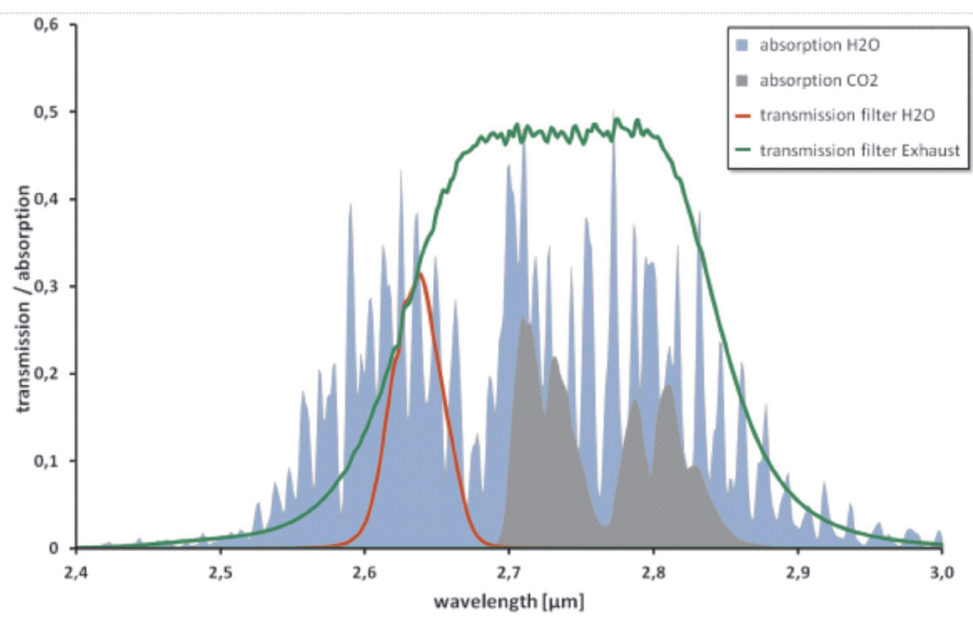

Fig. 1. Absorption spectrum of $\mathrm{CO}_{2}$ and $\mathrm{H}_{2} \mathrm{O}$ with used transmission filters Rys. 1. Widmo absorpcji $\mathrm{CO}_{2}$ i $\mathrm{H}_{2} \mathrm{O}$ z zastosowanymi filtrami wąskopasmowymi można dokonać pomiaru pojedynczego cyklu i tym samym otrzymywane wyniki nie są wystarczająco dokładne, a wykorzystanie tej techniki w silnikach seryjnych jest bardzo skomplikowane. Dlatego dziś analizę wymiany ładunku w cylindrze prowadzi się na podstawie wyników symulacji oraz pośredniej analizy wymiany ładunku wynikającej z wyników pomiarów.

\section{Aparatura pomiarowa}

\subsection{ICOS System}

System ICOS (Internal Combustion Optical Sensor) polega na zastosowaniu czujnika optycznego montowanego w cylindrze silnika spalinowego. Zasada pomiaru czujnika oparta jest na pomiarze bezdotykowym i polega na pomiarze absorpcji promieniowania podczerwonego przez rozpatrywany gatunek molekuł. Źródłem światła jest lampa halogenowa o widmie szerokopasmowym. Światło jest modulowane przez koło tnące (chopper) z częstotliwością $30 \mathrm{kHz}$ i przechodzi przez światłowód do czujnika, na którego końcu umieszczono stożek sondy z lustrem. Za pomocą lustra światło jest odbijane i trafia do drugiego światłowodu, a następnie do urządzenia detekcji. W zależności od zastosowanego wąskopasmowego filtra światła podczerwonego, który znajduje się w przedniej części detektora, określana jest ilość zaabsorbowanego światła przez molekuły, które stanowią przedmiot badań. $\mathrm{Na}$ podstawie tej zasady działania zostało przeprowadzonych wiele badań pozwalających na wykrycie paliwa w cylindrze, co zostało przedstawione w pracach $[1,2]$.

System wykorzystany w ramach projektu ICOS został zmodyfikowany w celu wykrycia absorpcji światła molekuł $\mathrm{CO}_{2}$ przy średniej długości fali światła podczerwonego około 2,7 $\mu \mathrm{m}$. Przy tej długości fali światło podczerwone absorbowane jest także przez cząsteczki wody (patrz rys. 1). $\mathrm{Z}$ tego powodu zastosowano dwa urządzenia do detekcji, które zsynchronizowano. Z jednej strony w szerokim zakresie widma możliwe jest zastosowanie, szerokopasmowego filtra obejmującego zarówno pasmo absorpcji części molekuł $\mathrm{CO}_{2}$, jak i molekuł $\mathrm{H}_{2} \mathrm{O}$ (filtr spalin), a $\mathrm{z}$ drugiej strony filtra wąskopasmowego, który wykrywa tylko absorpcję molekuły $\mathrm{H}_{2} \mathrm{O}$ (filtr $\mathrm{H}_{2} \mathrm{O}$ ). W ten sposób, po określaniu dwóch badanych względnych sygnałów gęstości $\left(\mathrm{CO}_{2}\right.$ i $\left.\mathrm{H}_{2} \mathrm{O}\right)$, możliwe jest określenie stężenia $\mathrm{CO}_{2}$. Szczegółowa procedura rozdzielenia sygnałów jest opisana $\mathrm{w}$ [3].

Uważne analizy przekrojów widma wykorzystanych w systemie filtrów wykazały, że współczynnik proporcjonalności $\chi$ wynosi 0,8 dla kompensacji sygnału gęstości wody. Na tej podstawie można określić związek między rejestrowanym sygnałem światła podczerwonego, a stężeniem $\mathrm{CO}_{2}$ - wzór (1),

wykorzystując sygnał gęstość wody $\mathrm{D}_{\text {н2о }}$, sygnał określony jako wydechowy $\mathrm{D}_{\text {Exhaust }} \mathrm{i}$ ciśnienie $\mathrm{p}$; $\alpha$ jest współczynnikiem całkowicie empirycznym. Kalibracja kilku systemów pomiarowych wykazuje, że współczynnik ten ma prawie stałą wartość. 


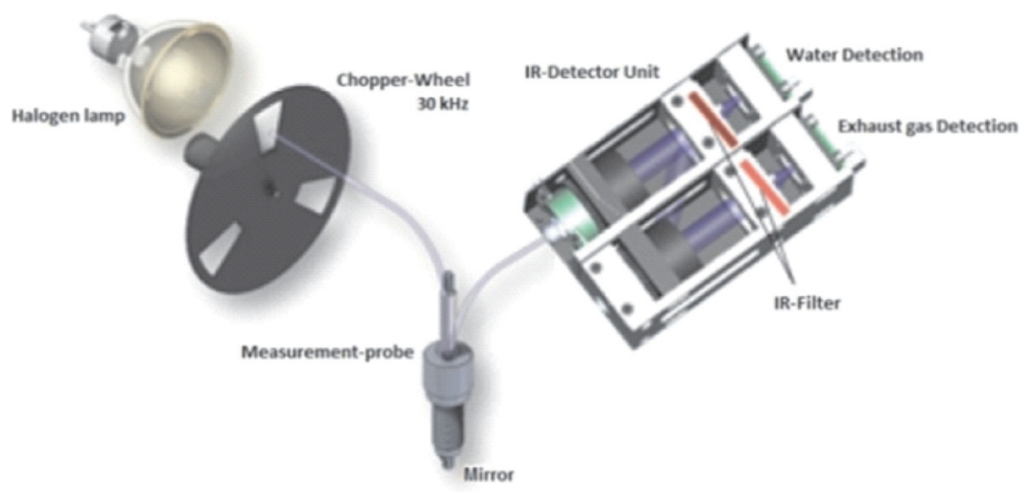

Fig. 2. Construction of the ICOS measuring system (up) and sensor with glow plug adapter (down)

Rys. 2. Budowa systemu pomiarowego ICOS (na górze) i czujnik z adapterem świecy żarowej (na dole)

$$
\mathrm{CO}_{2}=\alpha \cdot\left(\mathrm{D}_{\text {Exhaust }}-\chi \cdot \mathrm{D}_{\mathrm{H} 2 \mathrm{O}}\right) / \mathrm{p}
$$

with the measured density of the water $\mathrm{D}_{\mathrm{H} 2 \mathrm{O}}$ and the exhaust gas $\mathrm{D}_{\text {Exhaust }}$, and the pressure $\mathrm{p}$. Factor $\alpha$ has a purely empirical meaning. The calibration of several measuring systems has shown that this factor is almost constant.

In the following experiments a sensor head probe with a M5 thread was used, which was installed into a glow plug adapter (see Fig. 2). Thus, the measurement probe can be applied instead of the regular glow plug in the engine.

Figure 3 shows the construction of the measuring system at the test bench. The light source and the detection unit are located in the examined engine. The controlling and the data acquisition happen via a computer LAN connection from the control room.

\subsection{CSV System}

In the research simultaneously to the ICOS system the CSV-system by the firm Combustion for the determination of the EGR-rate in the cylinder of an engine has been applied. In this system special fast operating valves were used (Fig. 4) for fast sampling of the cylinder charge in the engine under operation.

The fast gas sampling enables to take a minimal assay from the cylinder during the compression phase and doesn't influence the compression ratio of the engine. The sample's volume depends on the type of exhaust-gas analyzer used in the measurements. In the case described here the Siemens Ultramat 5E for $\mathrm{CO}_{2}$ analysis was used (Fig. 5).

After collecting an adequate quantity of compressed gas an accumulator tube, it is quantified by a NDIR $\mathrm{CO}_{2}$ measuring analyzer. The fast gas sampling provides an indication of the $\mathrm{CO}_{2}$ concentration in the compression phase. The sampling takes place $30{ }^{\circ} \mathrm{CA}$ before TDC ignition. It is an average of the calculated concentration of $\mathrm{CO}_{2}$ over approximately 500 cycles over a range of $15^{\circ} \mathrm{CA}$ sampling.
W przeprowadzonych eksperymentach wykorzystano czujnik z głowicą z gwintem M5, który został zamontowany w adapterze świecy żarowej (rys. 2). Czujnik ten może być więc stosowany zamiast standardowej świecy żarowej w silniku.

Na rysunku 3 przedstawiono konstrukcję układu pomiarowego na hamowni silnikowej. Źródło światła i urządzenie służące do detekcji znajduje się przy badanym silniku. Urządzenia sterujące i system akwizycji danych są połączone z urządzeniami pomiarowymi przez łącze typu LAN.

\subsection{System CSV}

W ramach prowadzonych badań równocześnie z systemem ICOS do pomiaru stopnia recyrkulacji spalin $\mathrm{w}$ cylindrze silnika wykorzystano system CSV firmy Combustion. System ten wykorzystuje układ specjalnych szybkich zaworów do pobierania próbki gazu z cylindra pracującego silnika (rys. 4). Objętość pobieranych gazów w trakcie suwu sprężania jest na tyle mała, że nie wpływa na stopień sprężania silnika. Niezbędna objętość gazów, którą należy pobrać, zależy od wykorzystywanego analizatora spalin. W badaniach wykorzystano analizator spalin firmy Siemens Ultramat 5E (analizator $\mathrm{CO}_{2}$ ) - rys. 5 .

W czasie suwu sprężania za pomocą szybkiego pobierania gazów należy zassać minimalną ilość gazu. Po zebraniu odpowiedniej ilości zassanego gazu do przewodu, który pełni funkcję akumulatora, gazy zasysane są do analizatora pomiarowego $\mathrm{CO}_{2}$ typu NDIR. Zastosowanie szybkiego pobierania gazów pozwala na określenie stężenia $\mathrm{CO}_{2} \mathrm{w}$ fazie sprężania. Pobieranie gazów odbywa się $30{ }^{\circ} \mathrm{OWK}$ przed GMP. Określane w ten sposób jest średnie stężenie $\mathrm{CO}_{2}$ w ciągu około 500 cykli w zakresie $15^{\circ} \mathrm{OWK}$ (czas pobierania próbki).

\subsection{Silnik badawczy}

Dla porównawczego określenia funkcjonalności techniki wykorzystującej pomiar światła podczerwonego i

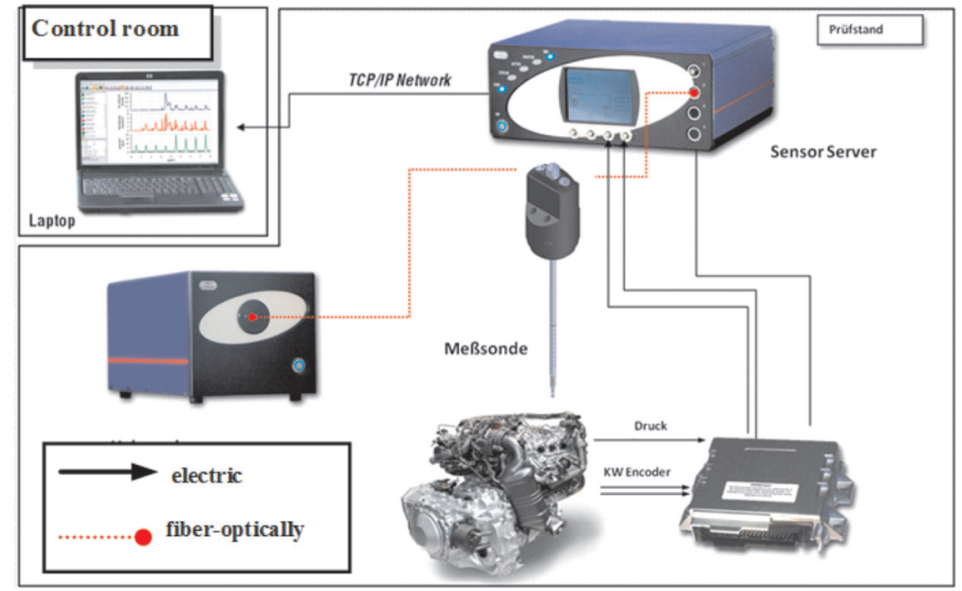

Fig. 3. ICOS system installation on the test bench Rys. 3. Instalacja systemu ICOS na hamowni silnikowej 
a)

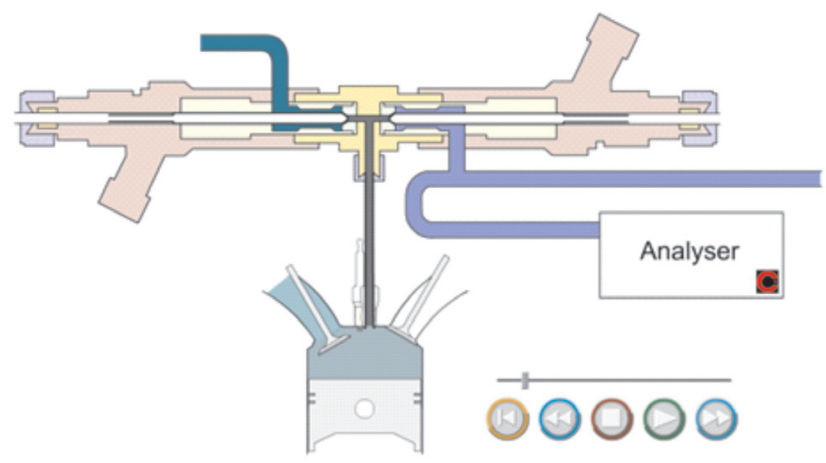

b)

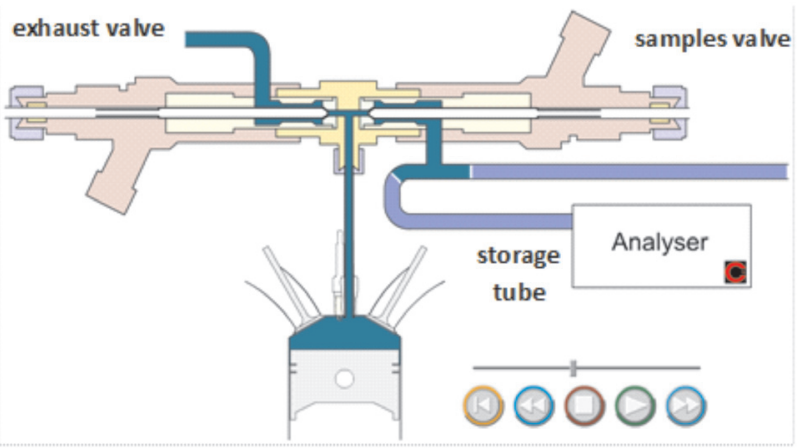

Fig. 4. CSV system overview: a) intake stroke, b) compression stroke

Rys. 4. Zasada działania systemu CSV: a) suw dolotu, b) suw sprężania, w którym zostaje pobrana próbka gazów znajdujących się w cylindrze

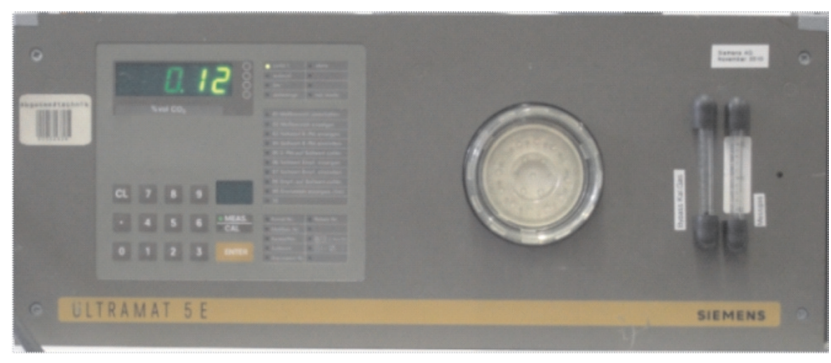

Fig. 5. Siemens Ultramat 5E analyser

Rys. 5. Analizator spalin firmy Siemens Ultramat 5E (analizator $\mathrm{CO}_{2}$ )

\subsection{Test engine}

To demonstrate comparatively the functionality of the infrared measurement technique and CSV system under engine operating conditions measurements were made on an AVL one cylinder research engine.

Figure 6a shows the engine test bench with the test measurement technology and the high pressure cooled EGR system (Fig. 6b). The one cylinder AVL engine has a cylinder head with 3 outlets (Fig. 6c). This allows maximum flexibility in terms of the applicable measurement technology. Via three separate holes the pressure indication, the infrared optical system and the fast gas sampling can be used simultaneously. The cylinder pressure is a necessary parameter for the determination of the $\mathrm{CO}_{2}$ concentration with the ICOS measurement system (see eq. 1).

The $\mathrm{CO}_{2}$ concentration in the cylinder can be varied by an exhaust gas recirculation (EGR). An external compressor allows the setting of any supercharging pressure. The external EGR rate, the internal EGR rate and the residual gas rate are defined as followed:

$$
\begin{aligned}
& \text { External EGR Rate }=\frac{\mathrm{CO}_{2, \text { SuctionTube }}-\mathrm{CO}_{2, \text { Environment }}}{\mathrm{CO}_{2, \text { Exhaust }}} \\
& \text { Internal EGR Rate }= \\
& =\text { External EGR Rate }+ \text { Re sidual gasrate }= \\
& =\frac{\mathrm{CO}_{2, \mathrm{IR} / \mathrm{CSV} \text {-Sensor }}-\mathrm{CO}_{2, \text { Environment }}}{\mathrm{CO}_{2, \text { Exhaust }}}
\end{aligned}
$$

systemu CSV w warunkach pracy rzeczywistego silnika spalinowego przeprowadzono badania z wykorzystaniem silnika jednocylindrowego (ZS, CR, doładowany) firmy AVL.

Na rysunku 6a przedstawiono hamownię silnikową z aparaturą pomiarową oraz wysokociśnieniowym chłodzonym systemem recyrkulacji spalin (rys. 6b). Jednocylindrowy silnik AVL posiada głowicę z trzema otworami (rys. 6c). Umożliwia to zainstalowanie całej techniki pomiarowej w jednym cylindrze. W trzech otworach zamontowano kolejno czujnik ciśnienia spalania, czujnik optyczny oraz układ szybkich zaworów do pobierania próbki gazu. Wszystkie te systemy mogą pracować jednocześnie. Pomiar ciśnienia w cylindrze jest koniecznym parametrem dla określenia stężenia $\mathrm{CO}_{2}$ z systemu pomiarowego ICOS (wzór (1)).

Stężenie $\mathrm{CO}_{2}$ w cylindrze może być zmieniane przez recyrkulację spalin (EGR). Zewnętrzna sprężarka umożliwia ustawienie dowolnego ciśnienia doładowania. Zewnętrzny EGR, wewnętrzny EGR i reszta spalin zdefiniowane są przez wzory (2)-(4).

Badania przeprowadzono dla różnych prędkości obrotowych i obciążenia silnika, różnych stopni EGR oraz ciśnienia dławienia w celu określenia możliwości pomiarowych systemu ICOS i CSV. Program badań przedstawiono na rysunku 7.

\section{Wyniki badań}

Na rysunku 8 przedstawiono zmierzone gęstości gazu przy różnych wartościach EGR w punkcie pracy $\mathrm{n}=1500$ $1 /$ min przy $\mathrm{p}_{\mathrm{mi}}=2,8$ bar i ciśnieniu doładowania 1,07 bar w kanale dolotowym. Zarejestrowane przebiegi są zgodne z przebiegiem ciśnienia w cylindrze. W celu określenia stężenia $\mathrm{CO}_{2}$ i stopnia recyrkulacji spalin jest istotna tylko faza sprężania do GMP. Po wtryśnięciu paliwa i rozpoczęciu procesu spalania sygnał nie jest już wykorzystywany.

Przedstawione wyniki pomiarów są średnią z ponad 100 cykli, ale analiza z cyklu na cykl jest również możliwa. Punkt pracy ze spalaniem, ale bez recyrkulacji spalin, ma wyższy poziom sygnału, a tym samym wyższe stężenie $\mathrm{CO}_{2}$ w stosunku do sygnału z czujnika IR zarejestrowanego bez spalania. Sytuacja taka jest spowodowana pozostałością 
a)

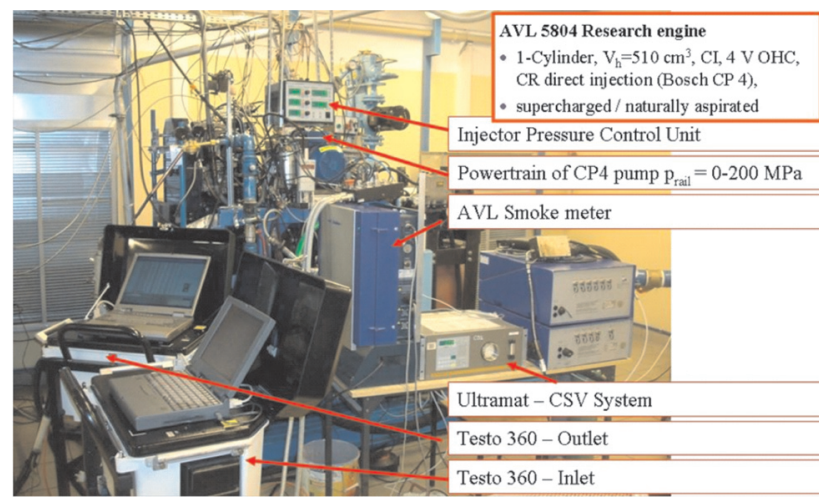

c)

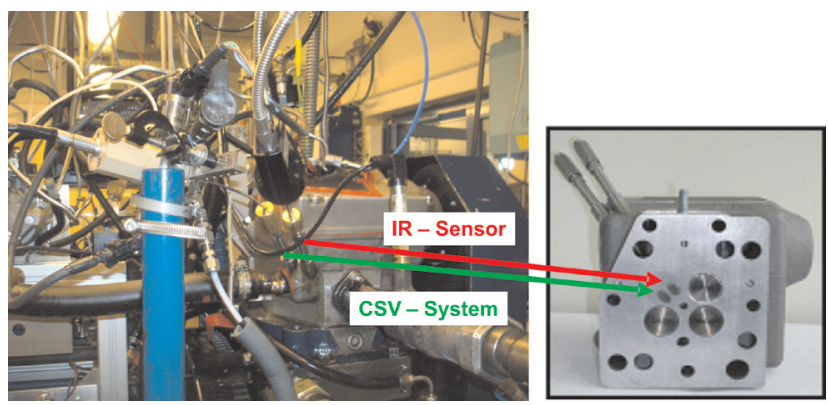

Re sidual gasrate $=$

$$
=\frac{\mathrm{CO}_{2, \mathrm{IR} / \mathrm{CSV}-\text { Sensor }}-\mathrm{CO}_{2, \text { SuctionTube }}-\mathrm{CO}_{2, \text { Environment }}}{\mathrm{CO}_{2, \text { Exhaust }}}
$$

The capability of the ICOS and CSV system has been examined at different engine speeds, loads, EGR rates and back pressures. Research program is shown in Fig. 7.

\section{Results}

Figure 8 shows the measured gas densities at an EGR variation in the operating point at $1500 \mathrm{1} / \mathrm{min}$ at 2.8 bar $\mathrm{p}_{\mathrm{mi}}$ and a supercharging pressure of 1.07 bar in the suction tube. The raw data show an analogue cylinder pressure. This is because the exhaust gas density is proportional to the cylinder pressure. To determine the concentration of $\mathrm{CO}_{2}$ and the EGR rate only the compression phase up to TDC is of significance. As soon as it is injected and the combustion starts, the signal is no longer utilized.

The presented measurement data show the average from over the 100 cycles but a single-cycle analysis is also possible. The operating point of combustion, but without EGR, shows a better signal strength and thus a higher $\mathrm{CO}_{2}$ concentration as the operating point without combustion. This behavior is caused by the residual gases in the cylinder. These are caused by an incomplete ejection of the combustion gases. An enhancement of the EGR rate leads to an increase of the measured exhaust gas density, the measurement signal of Fig. 8 includes the absorption of $\mathrm{CO}_{2}$ and $\mathrm{H}_{2} \mathrm{O}$.

The temperature of the fresh air and the returned exhaust gases is kept constant by a controllable intercooler. The suction tube pressure is controlled by an external compressor b)

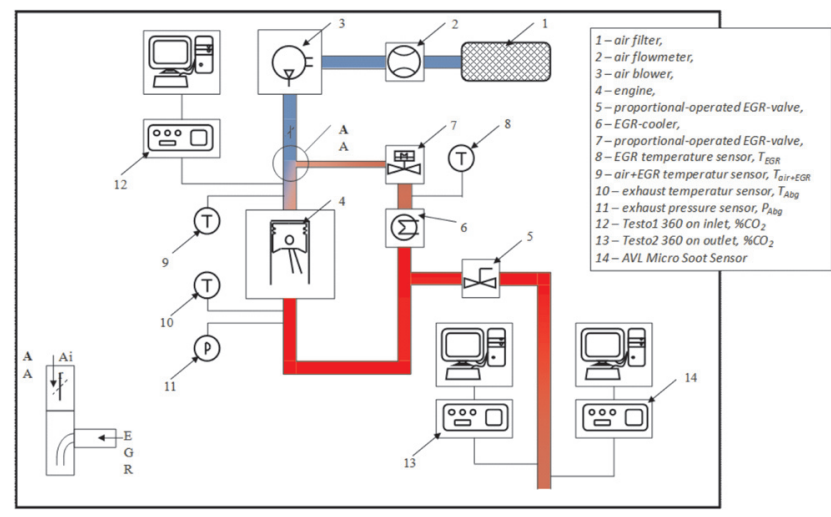

Fig. 6. Construction of the one-cylinder engine at the test bench (a), representation of the intake and exhaust system with exhaust gas recirculation (b), view on the cylinder head with three accesses to the ICOS-, CSV sensors and cylinder printing indication (c)

Rys. 6. Stanowisko z badawczym silnikiem jednocylindrowym (a), schemat układu dolotowego $i$ wylotowego z systemem recyrkulacji spalin (b), głowica cylindra z dostęem do czujnika ICOS, CSV oraz indykowania silnika (c)

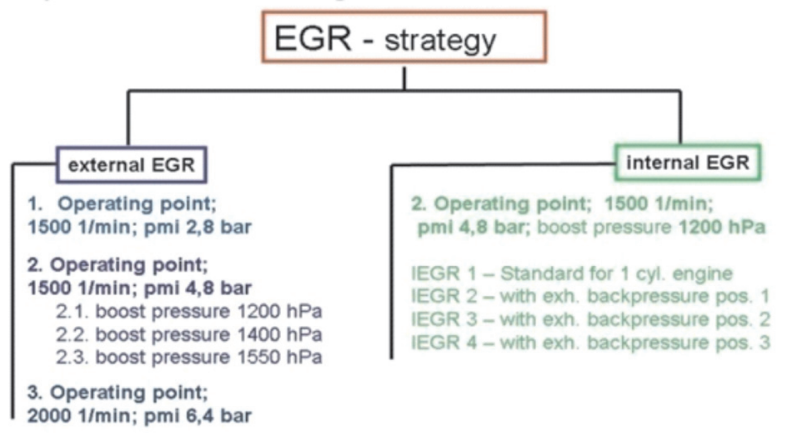

Fig. 7. Scope of research and investigation course Rys. 7. Zakres prowadzonych badań silnikowych

reszty spalin w cylindrze. Jest to spowodowane niecałkowitym przepłukaniem cylindra. Zwiększenie stopnia recyrkulacji spalin prowadzi do wzrostu gęstości spalin, co przedstawiono na rysunku 8 , gdzie mierzone sygnały to absorpcja $\mathrm{CO}_{2}$ i $\mathrm{H}_{2} \mathrm{O}$.

Temperatura świeżego ładunku i temperatura gazów spalinowych zawracanych do cylindra jest utrzymywana na stałym poziomie za pomocą zastosowanych chłodnic. Ciśnienie powietrza doładowanego jest sterowane z zewnętrznej sprężarki dla wszystkich stopni recyrkulacji spalin. Zmiana zmierzonej gęstości przez system ICOS jest więc określana tylko w oparciu o zmiany składu gazów znajdujących się w cylindrze w czasie sprężania, gdyż masa gazów pozostaje niemal na stałym poziomie przy zmianie stopnia EGR.

Na rysunku 8 przedstawiono sygnał gęstości wody (Density $\mathrm{H}_{2} \mathrm{O}$ ) w cylindrze w zależności od kąta obrotu wału 
for all the EGR rates. The change of the measured densities by the ICOS system is based therefore only on a change of the composition of material during the compression, the cylinder mass remains during the EGR variation nearly constant.

Figure 8 shows the crank angle resolved water density in the cylinder (Density $\mathrm{H}_{2} \mathrm{O}$ ). The enhancement at the increasing EGR rate is much more moderate than the exhaust gas signal (Density Exhaust), consisting of $\mathrm{CO}_{2}$ and $\mathrm{H}_{2} \mathrm{O}$. The described raw data is converted into a real concentration of $\mathrm{CO}_{2}$ by formula 1. The result is shown in Fig. 9.

The empirical formula (1) is valid at a pressure range from 10 to $30 \mathrm{bar}$. The measurement results show in this range an almost constant trend. The optical parameters Density Exhaust, Density $\mathrm{H}_{2} \mathrm{O}$ and the cylinder pressure can be measured at the same time and crank angle resolved. For each cycle a mean value of the $\mathrm{CO}_{2}$ concentration according to the above described evaluation method is determined. Therefore, the EGR rate (internal EGR and external EGR) and the residual gas rate can be determined according to the formulas (2)-(4).

The results of the different engine speed and load are shown in Fig. 10. In this, ICOS measurements and fast gas sampling measurements are compared.

One can observe no impact on engine speed and load on the results. Applied measurement systems show similar results. The $\mathrm{CO}_{2}$ concentration in the intake port will be used as reference value for the evaluation. With an increasing EGR rate also the concentration of $\mathrm{CO}_{2}$ rises. The measured concentration in the cylinder is because of the residual gas mass higher than in the suction tube.

At the enhancement of the EGR rate, the measured $\mathrm{CO}_{2}$ concentration in the suction tube increases
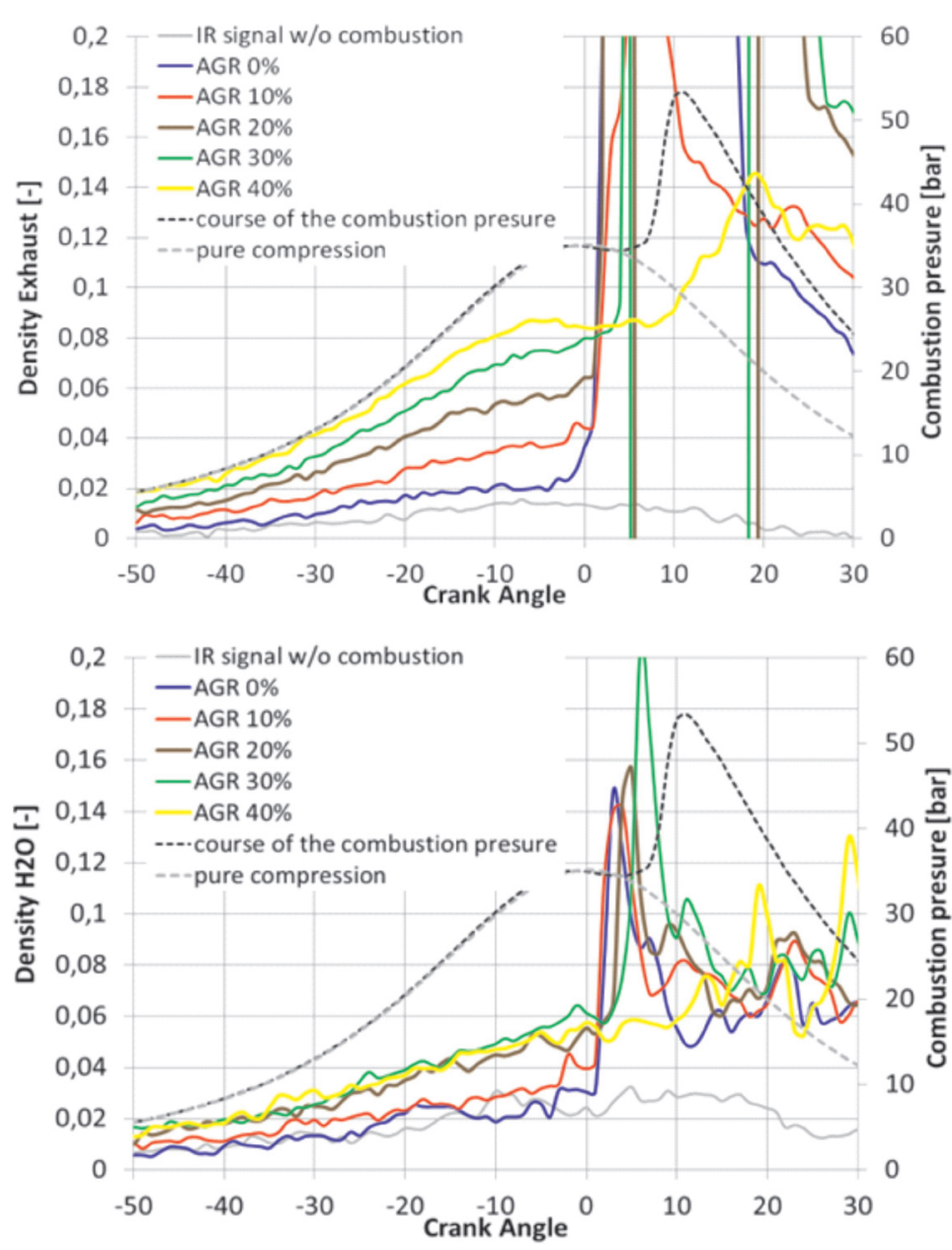

Fig. 8. $\mathrm{CO}_{2}$ density (up) and $\mathrm{H}_{2} \mathrm{O}$ density (down) for an EGR variation at $1500 \mathrm{1} / \mathrm{min}$, 2.8 bar $\mathrm{p}_{\mathrm{mi}}$ and a supercharging pressure in the suction tube at $1.07 \mathrm{bar}$

Rys. 8. Zmierzone gęstości $\mathrm{CO}_{2}$ (góra) i $\mathrm{H}_{2} \mathrm{O}$ (dót) dla różnych wartości EGR przy prędkości obrotowej $1500 \mathrm{l} / \mathrm{min}$, średnim ciśnieniu indykowanym $p_{m i}=2,8$ bar $i$ ciśnieniu doładowania w przewodzie dolotowym 1,07 bar

korbowego. Zwiększanie stopnia recyrkulacji spalin wpływa na ten sygnał znacznie mniej niż na wzmocnienie sygnału gęstości spalin (Density Exhaust), składającego

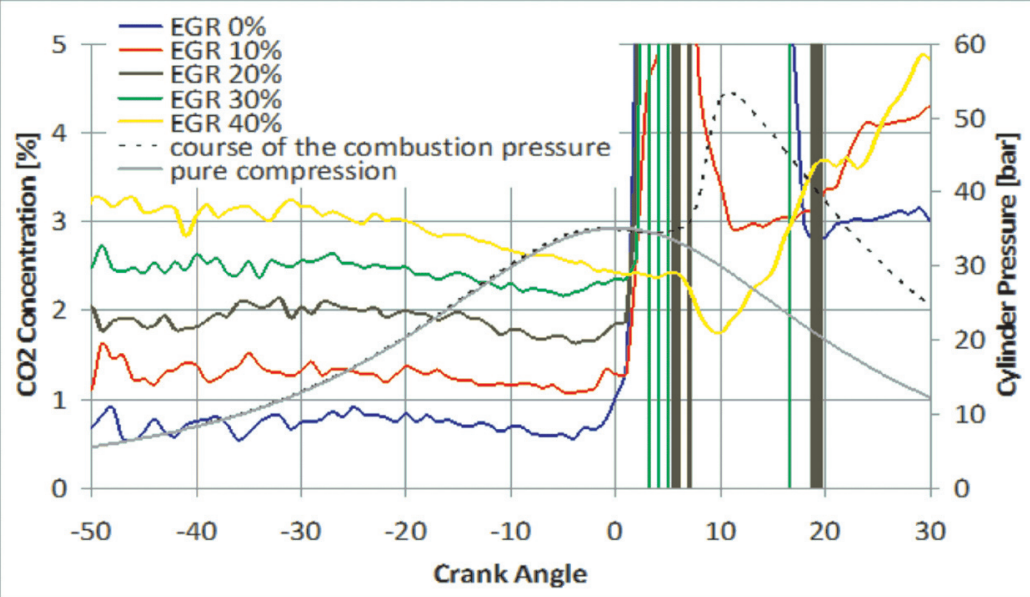

Fig. 9. $\mathrm{CO}_{2}$ concentration for an EGR variation at $15001 / \mathrm{min}$ at 2.8 bar $\mathrm{p}_{\mathrm{mi}}$ and a supercharging pressure of 1.4 bar in the suction tube

Rys. 9. Stężenie $\mathrm{CO}_{2}$ dla zmiennego EGR przy prędkości obrotowej 1500 1/min, obciązeniu $p_{m i}=2,8$ bar $i$ ciśnieniu doladowania $w$ przewodzie dolotowym 1,4 bar się z $\mathrm{CO}_{2} \mathrm{i}_{2} \mathrm{O}$. Przekształcenia surowych danych pomiarowych na rzeczywiste stężenie $\mathrm{CO}_{2}$ dokonano zgodnie $\mathrm{z}$ wzorem 1 . Jego wyniki przedstawiono na rys. 9.

Wzór (1) można stosować w zakresie ciśnień od 10 do 30 bar. Wyniki pomiarów wykazują w tym zakresie prawie stałą tendencję zmian. Sygnały optyczne gęstości spalin i pary wodnej (Density Exhaust, Density $\mathrm{H}_{2} \mathrm{O}$ ) oraz ciśnienie w cylindrze można zmierzyć w tym samym czasie, w zależności od kąta obrotu wału korbowego. W każdym cyklu pracy silnika średnia wartość stężenia $\mathrm{CO}_{2}$ została określona według opisanej powyżej metody. W związku z tym stopień recyrkulacji spalin (EGR wewnętrzny i EGR zewnętrzny) oraz ilość reszty spalin pozostających w cylindrze może być określona zgodnie z wzorami (2), (3) i (4). 


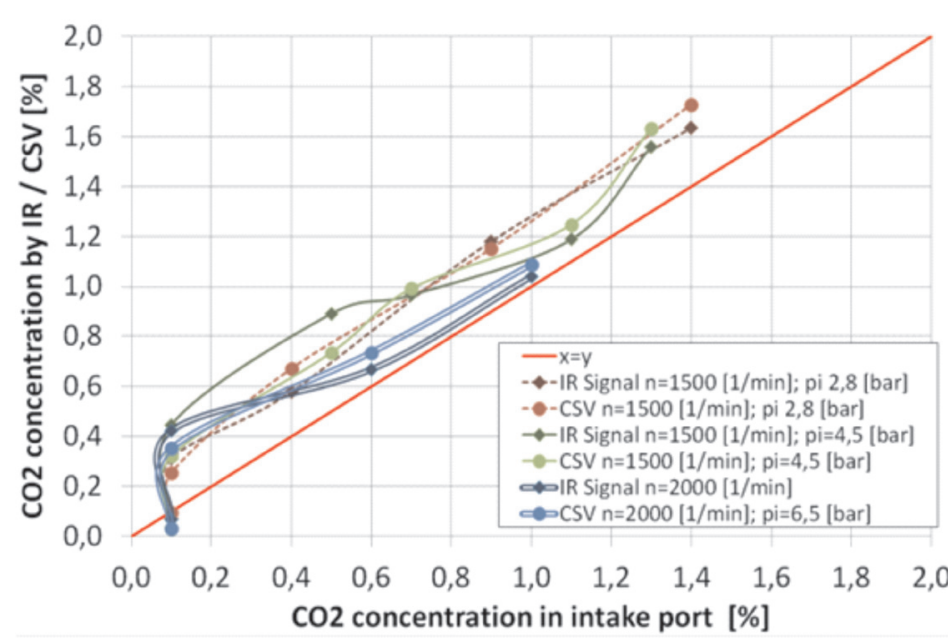

Fig. 10. Comparison of the measured $\mathrm{CO}_{2}$ concentration with the IR- and CSVSystems for an EGR variation at $15001 / \mathrm{min}$ and $\mathrm{p}_{\mathrm{mi}}=2.8 \mathrm{bar}$

Rys. 10. Porównanie wyników koncentracji $\mathrm{CO}_{2}$ dla pomiarów systemami IR $i$ CSV dla różnych stopni recyrkulacji spalin przy prędkości obrotowej $15001 / \mathrm{min} i$ obciążeniu $p_{m i}=2,8$ bar

and the $\mathrm{CO}_{2}$ concentration in the cylinder rises almost proportionally. The CSV and IR measuring technologies show a good accordance.

By using the formulas 2 and 3 it is possible to measure the internal EGR rate through the external EGR rate. The results are shown in Fig. 11. The represented data are from the IR measurement technology.

With formula 4 the residual gas rate can be determined. The measurements show that the residual gas rate is almost independent from the EGR rate and in a range from $6 \%$ to $8 \%$. This agrees with the observations of [4].

An EGR variation in the operating point was performed at $1500 \mathrm{1} / \mathrm{min}$ and 4.8 bar $\mathrm{p}_{\mathrm{mi}}$, and at $1200 \mathrm{mbar}, 1400 \mathrm{mbar}$ and 1550 mbar supercharging pressure. Figure 12 shows the measured residual gas rates.

The residual gas rate in this operating point is in a range from $4 \%$ to $7 \%$. The measurement results show that neither the EGR rate nor the supercharging pressure any influence at
Porównanie wyników dla różnej prędkości obrotowej i obciążenia silnika są przedstawione na rysunku 10. Zawierają one pomiary wykonane za pomocą systemu ICOS oraz za pomocą szybkiego pobierania próbek gazu CSV.

Na rysunku 10 widoczny jest brak istotnego wpływu zarówno prędkości obrotowej, jak i obciążenia na otrzymane wyniki. Zastosowane systemy pomiarowe pokazują zbliżone wyniki. Wartość stężenia $\mathrm{CO}_{2} \mathrm{w}$ kanale dolotowym będzie w dalszych badaniach stosowana jako wartość zadana do oceny poprawności otrzymanych wyników. Zwiększając stopień recyrkulacji spalin zwiększa się również stężenie $\mathrm{CO}_{2}$ w cylindrze. Zmierzone stężenie w cylindrze jest większe niż to zmierzone w kanale dolotowym ze względu na pozostałe spaliny z poprzedniego cyklu.

Zwiększając udział EGR i mierząc stężenie $\mathrm{CO}_{2}$ w kanale dolotowym uzyskuje się prawie proporcjonalny wzrost stężenia $\mathrm{CO}_{2}$ w cylindrze pracującego silnika. Techniki pomiarowe CSV i IR wykazują dobrą wzajemną zgodność wyników.

Za pomocą wzorów (2) i (3) możliwe jest określenie wewnętrznego EGR znając udział EGR zewnętrznego. Otrzymane wyniki przedstawiono na rysunku 11. Są to wyniki wykorzystujące tylko sygnał z systemu pomiarowego czujnika IR.

Wykorzystując równanie (4) możemy określić również udział reszty spalin znajdujących się w cylindrze. Pomiary wykazały, że udział reszty spalin praktycznie nie zależy od stopnia recyrkulacji spalin i zawiera się w zakresie od $6 \%$ do $8 \%$. Jest to zgodne z obserwacjami opisanymi w pracy [4].

Zmianę stopnia recyrkulacji spalin przeprowadzono $\mathrm{w}$ punkcie pracy silnika określonym prędkością obrotową $\mathrm{n}=$ $=15001 / \mathrm{min}$ i obciążeniem $\mathrm{p}_{\mathrm{mi}}=4,8$ bar oraz przy zmiennym ciśnieniu doładowania: 1200 mbar, 1400 mbar i 1550 mbar. Na rysunku 12 przedstawiono udział reszty spalin w cylindrze w zależności od ciśnienia doładowania.

Zaobserwowano, iż udział reszty spalin w tym punkcie pracy zawiera się w zakresie od $4 \%$ do $7 \%$. Na podstawie

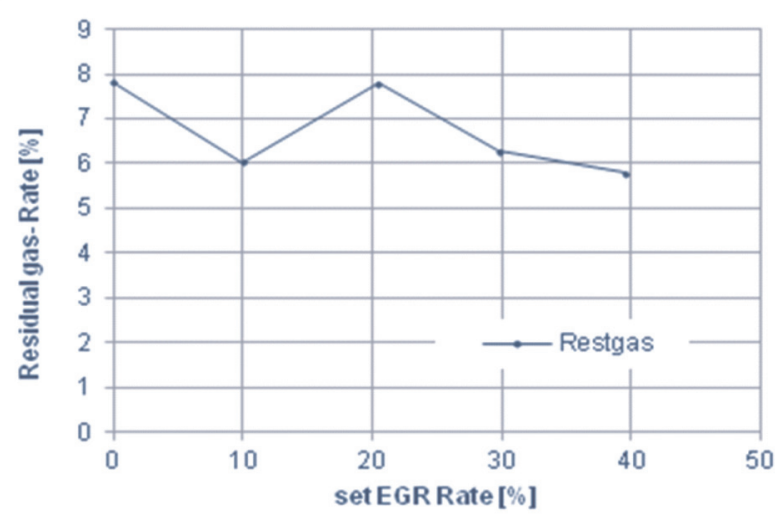

Fig. 11. Calculated internal and external EGR rate with the IR system (up) and the residual gas rate (down) for an EGR variation at $15001 /$ min and $\mathrm{p}_{\mathrm{mi}}=2.8$ bar

Rys. 11. Wyznaczony przy pomocy systemu IR stopień recyrkulacji spalin wewnętrzny i zewnętrzny (powyżej) $i$ udział reszty spalin w cylindrze (poni$\dot{z}$ ej) dla różnych wartości EGR przy $15001 / \mathrm{min} i p_{m i}=2,8$ bar 
this operating point on the residual gas rate. The operating point at $15001 / \mathrm{min}$ and 4.8 bar $\mathrm{p}_{\mathrm{mi}}$ has a lower residual gas mass than the operating point with 2.8 bar $\mathrm{p}_{\mathrm{mi}}$. This agrees with the results from [4].

At the operating point at 4.8 bar $\mathrm{p}_{\mathrm{mi}}$ and a supercharging pressure of 1200 mbar, the exhaust back pressure has increased by the adjustment of an exhaust flap. All points were measured without exhaust gas recirculation. A higher pressure in the exhaust manifold cause a worse cylinder flushing. The residual gas mass in the cylinder has thereby increased. This performance in the cylinder can be confirmed by the IR measurement, see Fig. 13. At a higher throttling the residual gas mass increases from about $4 \%$ to $10 \%$.

\section{Summary}

In a joint research project a new type of an infrared sensor for $\mathrm{CO}_{2}$ measurement was developed.

The different measurement methods have shown good accordance. Important information such as the EGR rate, the internal EGR rate and the residual gas rate can be determined out of the measured concentration of $\mathrm{CO}_{2}$.

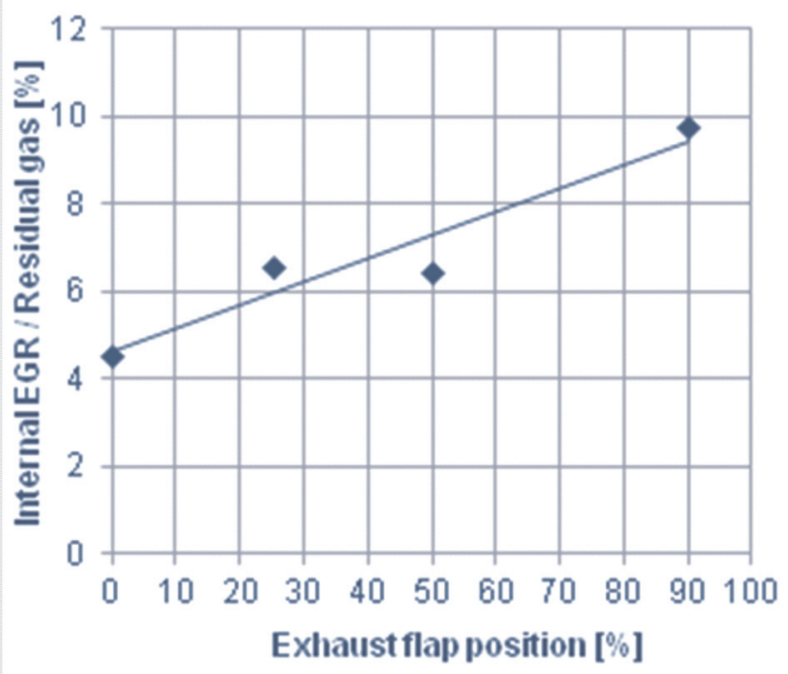

Fig. 13. Calculated residual gas rate with the IR system for an EGR variation at $15001 / \mathrm{min}$ and $\mathrm{p}_{\mathrm{mi}}=4.8$ bar for different exhaust back pressures

Fig. 13. Udział reszty spalin określony na podstawie pomiarów systemem IR dla zmiennego stopnia recyrkulacji spalin EGR przy prędkości obrotowej $1500 \mathrm{l} / \mathrm{min}$ i obciążeniu $p_{m i}=4,8$ bar, dla różnych wartości przeciwciśnienia wylotu spalin

The ICOS system allows a cycle-resolved analysis of the $\mathrm{CO}_{2}$ concentration, the internal and external EGR rate and the residual gas rate and is therefore a powerful tool to evaluate and optimize the charge cycle and the air mass equal distribution of modern diesel engines.

In the future an evolution of the system for the $\mathrm{CO}_{2}$ concentration is planned which can measure directly at $4.2 \mu \mathrm{m}$ and does not need water detection.

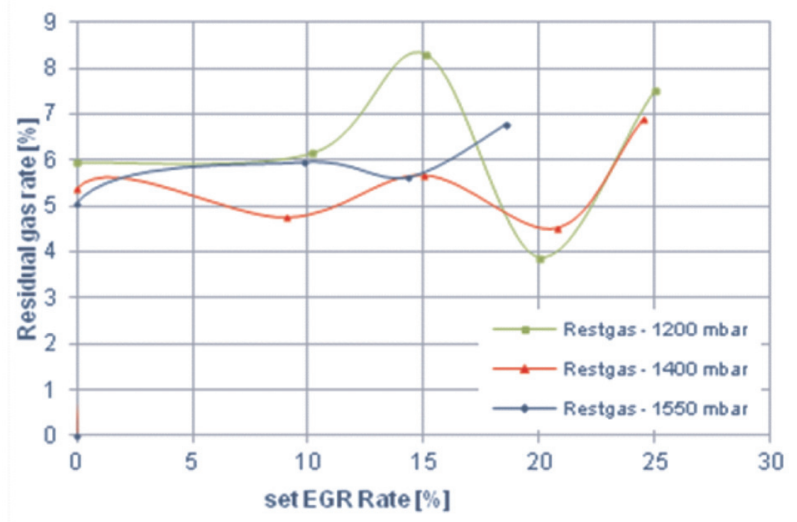

Fig. 12. Calculated residual gas rate with the IR system for an EGR variation at $15001 / \mathrm{min}$ and $\mathrm{p}_{\mathrm{mi}}=4.8 \mathrm{bar}$ with different supercharging pressures

Rys. 12. Udział reszty spalin określony na podstawie pomiarów systemem IR dla zmiennego stopnia recyrkulacji spalin EGR przy prędkości obrotowej $15001 /$ min i obciązeniu $p_{m i}=4,8$ bar, dla różnych wartości ciśnienia doładowania

otrzymanych wyników można stwierdzić, że ani udział EGR, ani ciśnienie doładowania $\mathrm{w}$ tym punkcie pracy nie wpływają znacząco na wartości udziału reszty spalin w cylindrze.

W punkcie pracy przy $n=15001 / \mathrm{min} \mathrm{i}_{\mathrm{mi}}=4,8$ bar masa reszty spalin jest niższa niż $\mathrm{w}$ punkcie pracy, $\mathrm{w}$ którym $\mathrm{p}_{\mathrm{mi}}$ wynosiło 2,8 bar. Jest to zgodne $\mathrm{z}$ wynikami przedstawionymi w pracy [4].

$\mathrm{W}$ punkcie pracy przy $\mathrm{p}_{\mathrm{mi}}=4,8$ bar i ciśnieniu doładowania 1200 mbar, zwiększono ciśnienie dławienia w kolektorze wylotowym przez zastosowanie przepustnicy. Wszystkich pomiarów dokonano bez zewnętrznej recyrkulacji spalin. Wyższe ciśnienie w kolektorze wylotowym spowodowało gorsze przepłukanie cylindra. W związku z tym nastąpiło zwiększenie masy reszty spalin w cylindrze. Potwierdza to pomiar stężenia gazu w cylindrze z wykorzystaniem czujnika IR (rys. 13). Zwiększenie dławienia wylotu spalin powoduje wzrost udziału reszty spalin w cylindrze od około $4 \%$ do $10 \%$.

\section{Podsumowanie}

W ramach wspólnego projektu badawczego został opracowany nowy typ czujnika podczerwieni do pomiaru $\mathrm{CO}_{2}$.

Zastosowane porównawcze metody pomiarowe wykazały dobrą zgodność uzyskiwanych wyników. Ważne informacje, takie jak udział zewnętrznego EGR, udział EGR wewnętrznego oraz udział reszty spalin mogą być ustalane na podstawie pomiaru stężenia $\mathrm{CO}_{2}$ systemem typu IR.

System ICOS pozwala na analizę z cyklu na cykl umożliwiającą określenie stężenia $\mathrm{CO}_{2}$, EGR-u wewnętrznego i zewnętrznego oraz udziału reszty spalin, a zatem jest potężnym narzędziem do oceny i optymalizacji wymiany ładunku w cylindrze i równomiernego napełniania cylindrów w nowoczesnych silnika wysokoprężnych.

W przyszłości planowana jest ewolucja omawianego systemu dla pomiaru stężenia $\mathrm{CO}_{2}$, w którym planowany jest bezpośredni pomiar absorpcji $\mathrm{CO}_{2}$ za pomocą filtra $4,2 \mu \mathrm{m} \mathrm{i}$ nie będzie on wymagał pomiaru stężenia pary wodnej. 


\section{Nomenclature/Skróty i oznaczenia}

ICOS Internal Combustion Optical Sensor/wewnętrzny optyczny czujnik spalania

CSV Combustion Sampling Valve/zawór poboru próbek spalin

$\mathrm{p}_{\mathrm{mi}} \quad$ Mean Indicated Presure/średnie ciśnienie indykowane

EGR Exhaust Gas Recirculation/stopień recyrkulacji spalin

$\mathrm{CO}_{2}$ carbon dioxide/dwutlenek węgla

Density Exhaust Density $\mathrm{CO}_{2}$ and $\mathrm{H}_{2} \mathrm{O} /$ gęstości $\mathrm{CO}_{2}$ i $\mathrm{H}_{2} \mathrm{O}$

Density $\mathrm{H}_{2} \mathrm{O}$

Density $\mathrm{H}_{2} \mathrm{O} /$ gęstość $\mathrm{H}_{2} \mathrm{O}$

IR-Sensor

\section{Bibliography/Literatura}

[1] Grosch A., Beushausen V., Thiele O., Grzeszik R.: Crank angle resolved determination of fuel concentration and air/fuel ratio in a SI-internal combustion engine using a modified optical spark plug. SAE Technical Papers 2007-01-0644, 2007.

[2] Grosch A., Beushausen V., Thiele O.: Crank angle resolved determination of fuel-concentration and air/fuel-ratio in a SI-production engine by using a modified optical spark plug. Advanced Microsystems for Automotive Applications 2008 (Springer, 2008), pp.105-126.

[3] Vanhaelst R., Thiele O., Berg Th., Stellet H.-P., Wildhagen F., Hentschel W., Joerdens Ch., Czajka J., Wislocki K.: Entwicklung eines innermotorischen ioptischen Infrarot-Sensors zur Bestimmung der AGR- und Restgasrate in Otto- und Dieselmotoren, Motorische Verbrennung Aktuelle Probleme und modern Losungsansatze (XI Tagung), 14-15.03.2013, Ludwigsburg.

[4] Heywood J.B.: Internal Combustion Engine Fundamentals, McGraw-Hill 1988.

[5] Vanhaelst R., Hentschel W., Müller C., Czajka J.: Development of an optical swirl sensor for DI-diesel engines/ Rozwój optycznego czujnika zawirowania do silników o ZS z wtryskiem bezpośrednim, 2009-SS2-C096.

Thomas Berg, Dipl.-Phys. - R\&D Manager, LaVision $\mathrm{GmbH}$, Goettingen, Germany.

Mgr Thomas Berg-menadżer dzialu badawczo-rozwojowego LaVision GmbH, Goettingen, Niemcy.

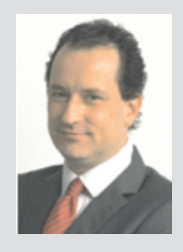

Hans-Peter Stellet - R \& D Department of Volkswagen AG, Wolfsburg, Germany.

Hans-Peter Stellet - pracownik dzialu badawczo-rozwojowego Volkswagen AG, Wolfsburg, Niemcy.

Mr. Werner Hentschel, DSc. - employee at Research and Development - Metrology Department in Volkswagen AG, Wolfsburg, Germany.

Dr Werner Hentschel - pracownik Działu Badawczo-Rozwojowego firmy Volkswagen, Wolfsburg, Niemcy. e-mail:werner.hentschel@volkswagen.de

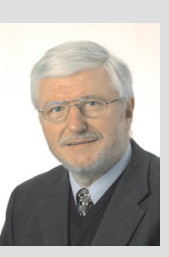

Jakub Czajka, DEng. - doctor at the Faculty of Machines and Transportation of Poznan University of Technology.

Dr inż. Jakub Czajka - adiunkt na Wydziale Maszyn Roboczych i Transportu Politechniki Poznańskiej.

e-mail: jakub.czajka@put.poznan.pl

Ireneusz Pielecha, DSc., DEng. - doctor at the Faculty of Working Machines and Transportation of Poznan University of Technology.

Dr hab. inż. Ireneusz Pielecha - adiunkt na Wydziale Maszyn Roboczych i Transportu Politechniki Poznańskiej.

e-mail: ireneusz.pielecha@put.poznan.pl

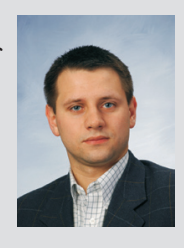

